\title{
Students' interest in physical education learning: Analysis of internal and external factors
}

\author{
Rama Kurniawan $^{\text {abcde } *(\mathbb{0})}$, Ari Wibowo Kurniawan ${ }^{\text {abd } \mathbb{C}}$, Dimas Wijaya ${ }^{\text {abc } \mathbb{C}}$ \\ Universitas Negeri Malang, Indonesia
}

Received: 25 July 2021; Accepted 17 September 2021; Published 07 December 2021

Ed 2021; 6(3): 385-393

\begin{abstract}
In physical education, learning interests are required so that the intentions of this meant learning are well accomplished. This research is aimed to find out the descriptions of students' interest factors when attending physical education learning at State Senior High School 2 Malang. This study employed a quantitative descriptive research design through survey methods. In order to obtain the research data, a questionnaire was employed as the research instrument with 329 students as the research subjects. After the data were collected, they were analyzed by using a type of descriptive statistical analysis. The results of this research indicated that students' interest in learning physical education of X class students in State Senior High School 2 Malang both of internal and external factors were classified as high categories. Internal factors influenced students' interests more during physical education learning compared to external factors. Overall, the activity factor and feeling of pleasure are the most influential factors for their involvement in physical education learning. Understanding that, students and teachers are suggested to look at intervening toward each above factors as an effort to improve their interest in learning.
\end{abstract}

Keywords: students' interest; learning interest; physical education

https://doi.org/10.25299/sportarea. 2021.vol6(3).7402

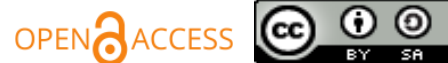

Copyright @ 2021 Rama Kurniawan, Ari Wibowo Kurniawan, Dimas Wijaya

Corresponding Author: Rama Kurniawan, Department of Physical Education, Health and Recreation, Faculty of Sport Science, Universitas Negeri Malang, Malang, Indonesia

Email: rama.kurniawan.fik@um.ac.id

How to Cite: Kurniawan, R., Kurniawan, A. W., \& Wijaya, D. (2021). Students' interest in physical education learning: Analysis of internal and external factors. Journal Sport Area, 6(3), 385-393. https://doi.org/10.25299/sportarea. 2021.vol6(3).7402

Authors' Contribution: a - Study Design; b - Data Collection; c - Statistical Analysis; d - Manuscript Preparation; e - Funds Collection

\section{INTRODUCTION}

Physical Education (PE) is defined as a subject that has been required by the government through the Indonesian Ministry of Education and Culture for all school levels from Elementary School to Higher Education (Mukhlis et al., 2020). PE holds as a subject which main element of learning involves physical activity as an instrument to achieve students' learning objectives (Pratiwi \& Oktaviani, 2018). In depth, this subject doesn't entail acquiring physical abilities only, however it more holds a learning that promotes whole personal growth, including movement, mental, social, and other aspects (Bailey, 2018; Butcher, 1972; Sudarsini, 2013). To accomplish these advancements, good interaction between teachers and students is necessitated in the learning process. Therefore, teachers are demanded to provide various learning in the delivery of material, present encouragement, enthusiasm, and raising students' attention. Furthermore, students are expected to keep their motivation and interest while engaging in PE learning. PE specifically provides opportunities for students to undergo variations in learning experiences through play activities, 
sports, and other physical activities that are arranged systematically, directed, and planned in the learning process, including own interests have an important role (Zulfa \& Kurniawan, 2019). The greater the interest of students, the better the learning activities (Shen et al., 2007). The existence of a strong interest in students during PE learning will encourage a high desire to follow the material in the next lesson (Webster et al., 2011). However, if the students are not interested in learning, particularly in the teaching material, what happens next is that the student will not be serious about learning (Slameto, 2010).

Feelings of interest are more directed to a sense of more and an attachment to the form of activity even though no one instructs it (Pratiwi, 2017). If it is applied to the physical learning process, interest will play an important role, because PE requires interest to be able to enhance students' physical engagement during PE classes (Chen et al., 2019). Several other views agree that interest in learning is an impulse that arises in a person who can improve learning habits (Lestari, 2015), and learning outcomes (Nurhasanah \& Sobandi, 2016). Consequently, students must consider their physical and bodily conditions in order to adapt to the expectations and regulations of PE classes. Internal interest (individual interest) and external interest (situational interest) are classified as the two divisions of interests in the PE class. Individual interest is associated with a person's propensity to participate in activities. Individual interest is believed to be a factor of interest that greatly influences student learning (Ainley, 2010). While situational interest tends to be related to certain conditions in a person's environment so that it can influence individual to do something (Ainley et al., 2002). Others' viewpoints even provide a larger category, namely subject interest, which is an interest based on an individual's propensity for a certain issue that motivates someone to take action (Chen \& Wang, 2017). PE is sometimes seen as a less significant learning subject for most students when it is evaluated only for the national exam. This subject is just as essential as other subjects if students pay a lot of attention because they need a healthy and fit physical condition as well as a high level of concentration. Seeing the importance of aspects of students' interests in improving the quality of the PE learning process, it is necessary to find out the obvious conditions of students' interest during PE learning.

Several previous studies on students' interest in physical education have been conducted. However, these studies still involved a small sample size, namely 55 (Saleh \& Malinta, 2020), and 40 students (Dewi \& Sepriadi, 2021). As a consequence, this makes it difficult to generalize to the larger community. The results of these studies were still limited to measuring the degree of overall students' interest conditions. Another study by Maulani and Adnan (2019)a tried to describe interest based on both of internal and external factors. However, there is no further information on which specific factor dominates the two factors. Therefore, this study uses a larger sample size and also focuses on obtaining more detailed information related to the dominant factors in influencing students' interests.

This research is quite considerable and needed over students concerning their interest in PE learning. Because if students' interest has risen, automatically, they will be motivated and actively associated in learning (Harackiewicz et al., 2008). The aim of this study is to describe students' interest in learning physical education. The research is also showing another perspective using of both internal and external factors. This research will show which factors are more dominant in influencing the student's interest in learning. The results of this study are also expected to be utilized by teachers at the school as baseline data for improving the effective strategies to increase students' interest and their engagement in physical education class.

\section{METHOD}

In order to answer the research problem, a quantitative descriptive research model with a survey method was employed. The variable used as the focus in this study was the student's interest. It was measured by internal factors consisting of enjoyment, attention, attraction, and activity. Other factors that were measured including peers, teachers, family, and facilities. The total research subjects that had been involved in this research were 329 students in class X at State Senior High School 2 Malang. The characteristics of the research subjects can be seen in table 1. 
Table 1. Subject Characteristics

\begin{tabular}{|c|c|c|c|c|c|c|}
\hline \multirow{3}{*}{ Subject Characteristics } & \multicolumn{4}{|c|}{ Gender } & \multirow{2}{*}{\multicolumn{2}{|c|}{$\begin{array}{c}\text { Total } \\
\text { N (329) }\end{array}$}} \\
\hline & \multicolumn{2}{|c|}{ Male (N =123 ) } & \multicolumn{2}{|c|}{ Female (N = 206$)$} & & \\
\hline & $\mathbf{F}$ & $\%$ & $\mathbf{F}$ & $\%$ & $\mathbf{F}$ & $\%$ \\
\hline \multicolumn{7}{|l|}{ Age (Years) } \\
\hline 15 & 35 & 28.5 & 64 & 31.1 & 99 & 30.1 \\
\hline 16 & 85 & 69.1 & 128 & 62.1 & 213 & 64.7 \\
\hline 17 & 3 & 2.4 & 12 & 5.8 & 15 & 4.6 \\
\hline 18 & 0 & 0 & 2 & 1 & 2 & 0.6 \\
\hline \multicolumn{7}{|l|}{ Class } \\
\hline Science & 50 & 40.7 & 120 & 58.3 & 170 & 51.7 \\
\hline Social & 61 & 49.6 & 66 & 32 & 127 & 38.6 \\
\hline Language & 12 & 9.8 & 20 & 9.7 & 32 & 9.7 \\
\hline \multicolumn{7}{|l|}{ Parents Occupation } \\
\hline PNS/TNI/Polri & 39 & 31.7 & 74 & 35.9 & 113 & 34.3 \\
\hline Private employee & 45 & 36.6 & 78 & 37.9 & 123 & 37.4 \\
\hline Driver & 3 & 2.4 & 2 & 1 & 5 & 1.5 \\
\hline Entrepreneur & 34 & 27.6 & 50 & 24.3 & 84 & 25.5 \\
\hline Others & 2 & 1.6 & 2 & 1 & 4 & 1.2 \\
\hline \multicolumn{7}{|l|}{ Routine Exercise (a week) } \\
\hline 0 - 2 days & 99 & 80.5 & 154 & 74.8 & 253 & 76.9 \\
\hline 3 - 4 days & 1 & 0.8 & 5 & 2.4 & 6 & 1.8 \\
\hline 5 - 7 days & 23 & 18.7 & 47 & 22.8 & 70 & 21.3 \\
\hline
\end{tabular}

The instrument employed in this research was a non-test instrument where a questionnaire was utilized as a medium for data collection. Researchers made compiled a questionnaire by adapting from Sunaryo (2016). The content validation procedure involved a psychologist and 2 PE learning experts. After going through the process of language revision and the appropriateness of the content from the results of expert judgment, the questionnaire was then tested to obtain the validity and reliability of the instrument. Among the 54 questions prepared, only 37 questions were valid and met a reliability value of 0.899 (Cronbach's Alpha). The data collection technique was carried out through the provision of online-based research questionnaires to research subjects, namely class $X$ students. In collecting this data the researchers took 3 weeks due to the implementation of Learning From Home (LFH) during the covid-19 pandemic. Analysis of the data uses the type of quantitative descriptive analysis. The descriptive analysis included the calculation of the frequency and percentage of research subjects. The calculated data were determined into five classifications, namely very low, low, medium, high, and very high.

\section{RESULTS AND DISCUSSION}

Based on the results of data analysis, this research obtained the descriptive data of students' interest in learning PE. Overall data analysis from both of internal and external factors were carried out to see the data percentages. Within the both factors of students' interest in PE learning at State Senior High School 2 Malang, it can be observed as below:

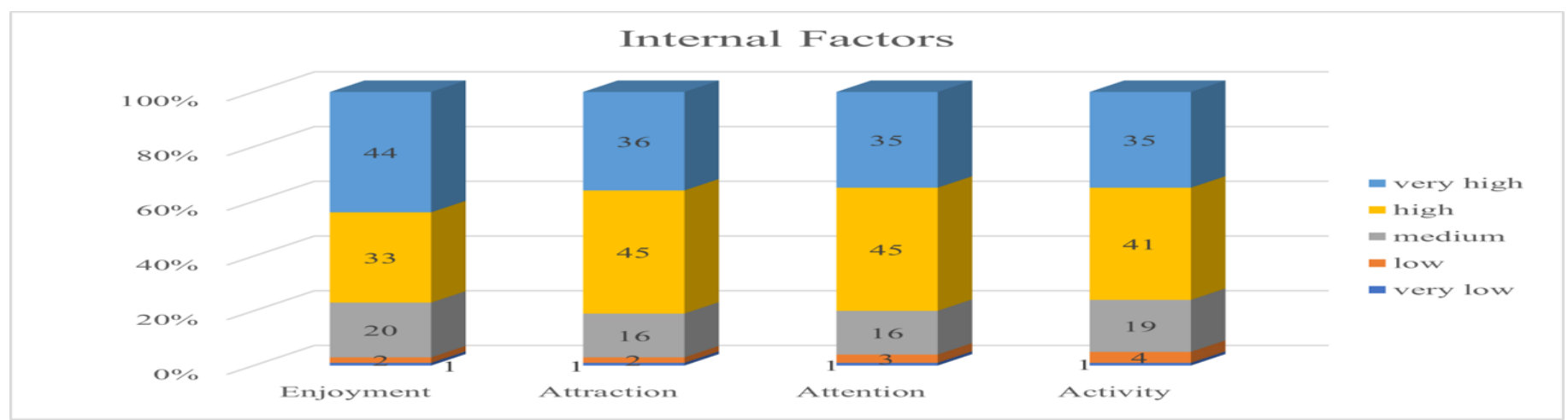

Graph 1. Percentage of Internal Factor 
In graph 1, it can be seen that internal factors, high and very high categories dominated the conditions of students' interest. The percentage of the very high category of $44 \%$ was enjoyment, for the high category attraction and attention had a relatively same percentage figure that was equal to $45 \%$. For the medium category, enjoyment also represented the number $20 \%$. For the low category, the activity factor had a large percentage compared to other factors, which was $4 \%$. For the very low category, all internal factors of interest had the same percentage of $1 \%$.

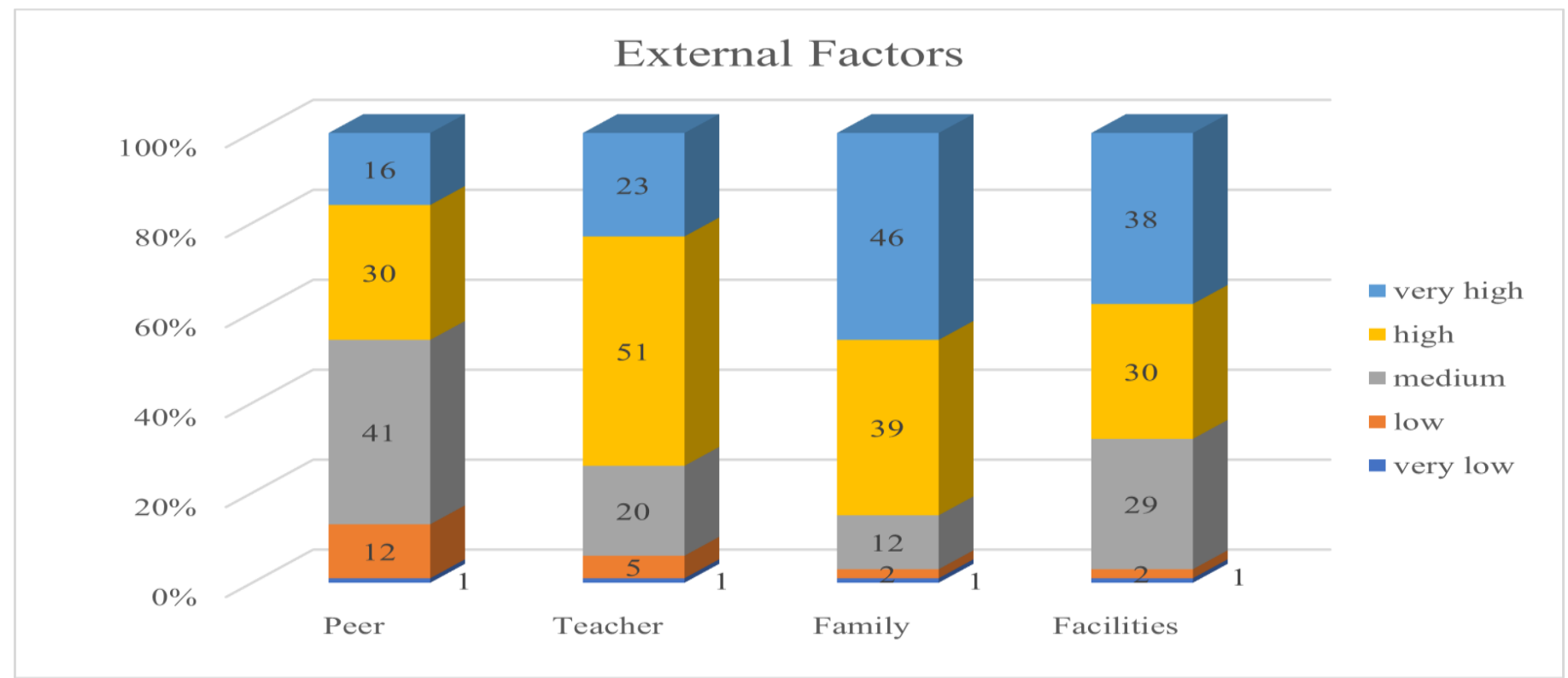

Graph 2. Percentage of External Factors

The calculation results of external factors were shown in graph 2 where family factors were the factors with the largest percentage in the very high category of $46 \%$. In the high category, the teacher factor affected the acquisition of a percentage of $51 \%$. In the medium category, the friend factor obtained the highest score with a percentage of $41 \%$. In addition, the friend factor also had the highest percentage compared to other external factors for the low category at $12 \%$. Furthermore, for the very low category, each external factor had the same percentage of $1 \%$.

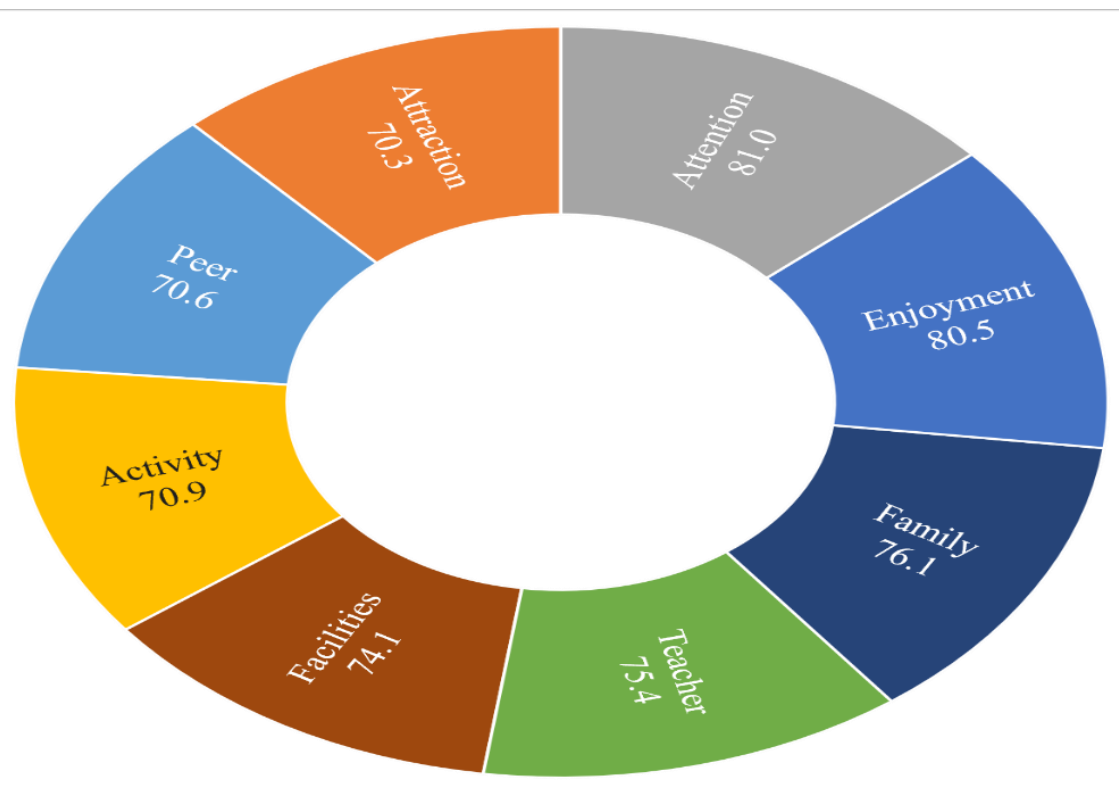

Enjoyment

- Attraction

- Attention

- Activity

Peer

Teacher

- Family

Facilities

Graph 3. Distribution of Dominant Factors of Students' Interest 
If we look at graph 3 above, it can be seen that the attention factor and the enjoyment factor were the most influencing factors for students' interest. They were $81 \%$ and $80.5 \%$. These two internal factors had the biggest picture compared to other interest factors. Internal factors, namely feelings of interest (70.3\%) and activity $(70.9 \%)$ and other external factors, namely peers $(70.6 \%)$ became the three lowest factors of the overall students' interest in learning factors. All of these results indicated that internal factors tended to influence students' interest in PE learning more.

\section{Internal Factors}

In general, students' interest in PE learning in State Senior High School 2 Malang can be categorized highly which the evidence can be seen into the analysis in figures 1 and 2 above. The results of this research also indicated that internal factors can have more effect than external factors. This condition presented that if students have an interest in something then students will tend to focus greater attention on something they like (Simbolon, 2014). Even if the teacher allows students to choose their physical activity according to their expectation will also make them survive to continue to engage in physical activity and connecting in-class activity to their life outside the classroom (Otundo \& Garn, 2019).

Internal factors including enjoyment describe a person's positive mood. A person who has enjoyment or something that is liked in a certain way tends to understand the relationship between feelings and interests (Hidayat \& Asroi, 2013). Further enjoyment in certain lessons can affect students' learning interests during learning activities (Slameto, 2010). Feelings of attraction that give rise to one's interests greatly influence their response to something. People who have a high interest in certain things will have a tendency to be more attracted in the direction of the teacher and the subjects delivered (Pratiwi, 2017).

The findings revealed that a significant internal factor was presented by the attraction's role of student (see graph 1). A student engaged more in learning because they learn new something. Indicators to be able to know one's interests are obtained through the concentration of the mind and attention of the subject to learning because of attraction (Darmadi, 2017). This also applies when a person has a feeling of pleasure where when someone feels happy with an activity he/she does then he will focus on the activities he/she does. Therefore, it is important for teachers to always offer new and enjoyable activities for students to encourage maximum involvement in physical activity in PE classes (Huang \& Gao, 2013). Another determining factor for internal student demand is attention. Attention itself is impeached as a form of activity of a person's desire for observation by making other things worse (Hidayat \& Asroi, 2013). Based on the results of the study, the high level of student attention in following PE learning was due to the magnitude of students' responses to attention to PE learning. The form of their desire to move in learning had been come up because of a response or stimulus to the activities carried out. That was in line with the results of this research which revealed that activities factor was defined as the majority in the high classification. Specifically designed activities according to differences in skill levels each student will provide support for the expected mastery of competencies (Otundo \& Garn, 2019). There is a positive feeling of the activity they follow as well as a great curiosity that will participate in developing students' initial interest in the activity (Hidi \& Ann Renninger, 2006).

\section{External Factors}

In this part, students' interest was influenced by several external factors based on the data findings in this research. Although research results indicated an internal factor that tended to outweigh external factors, growing interest due to external factors need to as an important part of enhancing students' skill and knowledge (Ding et al., 2013). To gain interest through these external factors, teachers need to take several steps to manipulate and modify certain aspects of the student learning environment such as teaching materials (Ilmawati et al., 2017). Building motivational components into the course content could stimulate students' interest in moving and engaging in learning (Roure \& Pasco, 2018). Appropriate curriculum design can also be applied to increase students' interest so that it will contribute to increasing physical activity in the classroom (Chen et al., 2019). 
A interest-peer's role association emerged in this study. Students' interest was totally triggered by peer's environment which had an important part in this case. Peer's environment is a form of interaction with children who have the same identity and age (Slavin, 2018). Peers can provide motivation and a building atmosphere if someone is in a class (Saputro \& Pardiman, 2012). Apart from peers, the teacher factor is also very decisive. Teacher skills are one of the important factors in improving the learning process and learning interests as the learning process takes place (Sumyadi et al., 2020). Likewise in the context of PE teachers have an important role in increasing the interest of their students in PE classes as well as other sports activities (Gerina, 2011). The role of the teacher is very important in a learning activity taking place. Teachers are people who study directly with students in class, teachers play an important role in getting students academic, professional knowledge, spiritual, moral, and emotional. To support all that, it takes a qualified teacher, has a full sense of responsibility to carry out his duties properly (Kunandar, 2014).

It is noticeable that both of family and schools roles stimulated students for engaging more in learning tasks. This finding confirmed that the role of parents at home to guide and direct children can increase their learning interests (Watuliu, 2015). The family itself becomes the most important educational "institution" for students, a harmonious and warm family can provide education in a small scope, but instead has a decisive influence on education in a large scope such as education in the country, countries, and even the world (Rochanah, 2016). Thus, if students are in a good family environment then students' interest in learning will be helped to be good too. Family encouragement can also reinforce for children to always be physically active outside of school and keep them in fit condition (Sari, 2016). The existence of other external factors such as the availability of facilities and infrastructure in the caretaker learning process also shows a high influence on the interest of students. It is hoped that the better the completeness of the facilities and infrastructure of the sport they have, the higher the enthusiastic learning of students in the caretaker. Good management of sports facilities will support the quality of sports which further contributes to the effectiveness of PE learning in schools (Purnama, 2017).

\section{CONCLUSION}

Based on the results of research on students' interest in PE Learning, it is said that enjoyment, attention, attraction, and activity in PE learning are categorized into internal factors which further influence students' interest in following learning activities compared to external factors in the form of peers, teachers, and families. However, these conditions are not too different in numbers. Consequently, it is expect that teachers can still employ both factors as some triggers to improve students' interest in playing and doing task movement during PE learning. Teachers can also employ various strategies including improving the quality of their curriculum and teaching programs and continuing to improve competence through training to encourage the quality of teaching of their PE (CDC, 2010).

This study also has some limitations. the sample involved in the study is still only at the $\mathrm{X}$ grade level, so it is necessary to use a larger sample that represents each level in one school. The use of larger samples would allow the researcher to establish a comprehensive result. Although this research can provide an overview of student learning interests, further research needs to be done to see how the role of these factors affects students' interests qualitatively so that comprehensive information will be obtained regarding students' interests. A detailed description is needed to see why students can be optimally involved in PE learning at school. Subsequent research can also direct its focus on differences in gender factors, skill levels, economic status, and levels of physical activity outside of school. Especially gender and skill levels that correlate with high students' interest (Chen \& Darst, 2002). Both of internal and external factors are so critical for gaining the students' learning objectives. Future research focusing on students' interest also can provide an accurate study that will be used by teachers in preparing their teaching. 


\section{ACKNOWLEDGMENT}

The authors would like to thank the LP2M Universitas Negeri Malang for their publication grants. The authors also thank students who were involved in our research.

\section{CONFLICT OF INTEREST}

The authors declared no conflicts of interest in preparing this article. The result of this study was not affected by any parties or sponsors.

\section{REFERENCES}

Ainley, M. (2010). Interest. International Encyclopedia of Education, 612-617. https://doi.org/10.1016/B978-0-08-044894-7.00611-4

Ainley, M., Hidi, S., \& Berndorff, D. (2002). Interest, learning, and the psychological processes that mediate their relationship. Journal of Educational Psychology, 94(3), 545-561. https://doi.org/10.1037/00220663.94.3.545

Bailey, R. (2018). Sport, physical education and educational worth. Educational Review, 70(1), 51-66. https://doi.org/10.1080/00131911.2018.1403208

Butcher, C. A. (1972). Foundation of Physical Education. CV. Mosby Co.

CDC. (2010). Strategies to Improve the Quality of Physical Education. www.cdc.gov/HealthyYouth

Chen, A., \& Darst, P. W. (2002). Individual and situational interest: The role of gender and skill. Contemporary Educational Psychology, 27(2), 250-269. https://doi.org/10.1006/ceps.2001.1093

Chen, A., \& Wang, Y. (2017). The role of interest in physical education: A review of research evidence. In Journal of Teaching in Physical Education, 36(3), 313-322. https://doi.org/10.1123/jtpe.2017-0033

Chen, S., Sun, H., Zhu, X., Chen, A., \& Ennis (Posthumous), C. D. (2019). Learners' motivational response to the Science, PE, \& Me! curriculum: A situational interest perspective. Journal of Sport and Health Science, 10(2), 243-251. https://doi.org/10.1016/j.jshs.2019.11.001

Darmadi. (2017). Pengembangan Model dan Metode Pembelajaran Dalam Dinamika Belajar Siswa. Deepublish.

Dewi, R. P., \& Sepriadi. (2021). Minat Siswa SMP Terhadap Pembelajaran PJOK Secara Daring Pada Masa New Normal. Physical Activity Journal, 2(2), 205. https://doi.org/10.20884/1.paju.2021.2.2.3988

Ding, H., Sun, H., \& Chen, A. (2013). Impact of expectancy-value and situational interest motivation specificity on physical education outcomes. Journal of Teaching in Physical Education, 32(3), 253269. https://doi.org/10.1123/jtpe.32.3.253

Gerina, N. (2011). Basic Education Learners' Interest in Physical Education: Theoretical Aspects. Lase Journal of Sport Science. 2(2), 102-118.

Harackiewicz, J. M., Durik, A. M., Barron, K. E., Linnenbrink-Garcia, L., \& Tauer, J. M. (2008). The Role of Achievement Goals in the Development of Interest: Reciprocal Relations Between Achievement Goals, Interest, and Performance. Journal of Educational Psychology, 100(1), 105-122. https://doi.org/10.1037/0022-0663.100.1.105

Hidayat, S., \& Asroi. (2013). Manajemen Pendidikan: Substansi dan Implementasi dalam Praktik Pendidikan di Indonesia. Novindo Pustaka Mandiri.

Hidi, S., \& Ann Renninger, K. (2006). The four-phase model of interest development. Educational Psychologist, 41(2), 111-127. https://doi.org/10.1207/s15326985ep4102_4 
Huang, C., \& Gao, Z. (2013). Associations between students situational interest, mastery experiences, and physical activity levels in an interactive dance game. Psychology, Health and Medicine, 18(2), 233241. https://doi.org/10.1080/13548506.2012.712703

Ilmawati, H., Suherman, A., Friskawati, G. F., \& Sriningsih. (2017). The Effect of Physical Education Teaching Materials towards Situational Interest. IOP Conference Series: Materials Science and Engineering, 180, 012201. https://doi.org/10.1088/1742-6596/755/1/011001

Kunandar. (2014). Guru Profesional: Implementasi Kurikulum Tingkat Satuan Pendidikan (KTSP) dan Sukses Dalam Sertifikasi Guru. Rajagrafindo Persada.

Lestari, I. (2015). Pengaruh Waktu Belajar dan Minat Belajar terhadap Hasil Belajar Matematika. Formatif: Jurnal Ilmiah Pendidikan MIPA, 3(2), 115-125. https://doi.org/10.30998/formatif.v3i2.118

Maulani, I., \& Adnan, A. (2019). Minat Siswa Belajar Pendidikan Jasmani Olahraga dan Kesehatan. Jurnal Patriot, 1(3), 1077-1086. https://doi.org/10.24036/patriot.v1i3.380

Mukhlis, N. A., Kurniawan, A. W., \& Kurniawan, R. (2020). Pengembangan Pembelajaran Kebugaran Jasmani Unsur Kelincahan Berbasis Multimedia Interaktif. Sport Science and Health, 2(11), 566-581. https://doi.org/10.17977/um062v3i22021p40-53

Nurhasanah, S., \& Sobandi, A. (2016). Minat Belajar Sebagai Determinan Hasil Belajar Siswa. Jurnal Pendidikan Manajemen Perkantoran, 1(1), 128. https://doi.org/10.17509/jpm.v1i1.3264

Otundo, J. O., \& Garn, A. C. (2019). Student interest and engagement in middle school physical education: Examining the role of needs supportive teaching. International Journal of Educational Psychology, 8(2), 137-161. https://doi.org/10.17583/ijep.2019.3356

Pratiwi, E., \& Oktaviani, M. N. (2018). Dasar-Dasar Pembelajaran Pendidikan Jasmani Sekolah Dasar. CV. Pustaka Jati.

Pratiwi, N. K. (2017). Pengaruh Tingkat Pendidikan, Perhatian Orang Tua, dan Minat Belajar Siswa Terhadap Prestasi Belajar Bahasa Indonesia Siswa SMK Kesehatan di Kota Tangerang. Pujangga, 1(2), 31. https://doi.org/10.47313/pujangga.v1i2.320

Purnama, S. (2017). Pengaruh Manajemen Fasilitas Olahraga dan Layanan Guru terhadap Efektivitas Pendidikan Jasmani Olahraga dan kesehatan (Studi Pada Sekolah Menengah Atas Negeri di Kota Tasikmalaya). Journal Sport Area, 2(2), 105-114. https://doi.org/10.25299/sportarea.2017.vol2(2).704

Rochanah. (2016). Peranan Keluarga Sekolah dan Masyarakat dalam Menunjang Pembelajaran yang Efektif. Elementary: Islamic Teacher Journal, 4(1), 188-204. https://doi.org/10.21043/elementary.v4i1.1981

Roure, C., \& Pasco, D. (2018). The impact of learning task design on students' situational interest in physical education. Journal of Teaching in Physical Education, 37(1), 24-34. https://doi.org/10.1123/jtpe.2017-0046

Saleh, M. S., \& Malinta, S. S. (2020). Survei Minat Belajar Siswa dalam Mengikuti Pembelajaran Pendidikan Jasmani di SMPN 30 Makassar. Kinestetik, 4(1), 55-62. https://doi.org/10.33369/jk.v4i1.10347

Saputro, S. T., \& Pardiman, P. (2012). Pengaruh Disiplin Belajar dan Lingkungan Teman Sebaya Terhadap Prestasi Belajar Mahasiswa Program Studi Pendidikan Akuntansi Angkatan 2009 Fakultas Ekonomi Universitas Negeri Yogyakarta. Jurnal Pendidikan Akuntansi Indonesia, 10(1), 78-97. https://doi.org/10.21831/jpai.v10i1.923

Sari, M. (2016). Kontribusi Lingkungan Keluarga dan Aktivitas Fisik Terhadap Kesegaran Jasmani Anak Tunagrahita. Journal Sport Area, 1(1), 38-46. https://doi.org/10.30814/sportarea.v1i1.374 
Shen, B., Chen, A., \& Guan, J. (2007). Using achievement goals and interest to predict learning in physical education. Journal of Experimental Education, 75(2), 89-108. https://doi.org/10.3200/JEXE.75.2.89108

Simbolon, N. (2014). Faktor Faktor yang Mempengaruhi Minat Belajar Peserta Didik. Elementary School Journal Pgsd Fip Unimed, 1(2), 14-19. https://doi.org/10.24114/esjpgsd.v1i2.1323

Slameto. (2010). Belajar dan Faktor-Faktor yang Mempengaruhinya. Rineka Cipta.

Slavin, R. E. (2018). Educational Psychology: Theory and Practice (12th ed.). Allyn \& Bacon.

Subramaniam, P. R. (2010). Unlocking the Power of Situational Interest in Physical Education. Journal of Physical Education, Recreation \& Dance, 81(7), 38-49. https://doi.org/10.1080/07303084.2010.10598507

Sudarsini. (2013). Pendidikan Jasmani dan Olahraga. Universitas Negeri Malang.

Sumyadi, Y., Umasih, U., \& Syukur, A. (2020). The Effect of Teacher Teaching Skills and Student Interest on History Learning Outcomes. Journal of Education Research and Evaluation, 4(3), 315-320. https://doi.org/10.23887/jere.v4i3.28349

Sunaryo, S. (2016). Students' Interest in Learning Physical Education at State Junior High School of Tempel Sleman Special Province of Yogyakarta. Pendidikan Jasmani Kesehatan dan Rekreasi, 5(6), 1-8.

Watuliu, J. (2015). Peranan Komunikasi Keluarga Dalam Meningkatkan Minat Belajar Siswa SMU di Desa Warukapas Kecamatan Dimembe Kabupaten Minahasa Utara. Acta Diurna, 4(4), 1-14.

Webster, C., Mîndrilă, D., \& Weaver, G. (2011). The Influence of state motivation, content relevance and affective learning on high school students' intentions to use class content following completion of compulsory physical education. Journal of Teaching in Physical Education, 30(3), 231-247. https://doi.org/10.1123/jtpe.30.3.231

Zulfa, I. I., \& Kurniawan, A. W. (2019). Survei Kebugaran Jasmani Kelas VIII SMP Plus Asy-Syukur Kanigoro. Sport Science and Health, 1(3), 184-192. 